\title{
Retinitis pigmentosa, ataxia, and peripheral neuropathy
}

\author{
RR TUCK, JG MCLEOD \\ From the Department of Medicine, University of Sydney, Australia
}

SUMMARY The clinical features of four patients with retinitis pigmentosa, ataxia and peripheral neuropathy but with no increase in serum phytanic acid are reported. Three patients also had sensorineural deafness and radiological evidence of cerebellar atrophy. Nerve conduction studies revealed abnormalities of sensory conduction and normal or only mild slowing of motor conduction velocity. Sural nerve biopsy demonstrated a reduction in the density of myelinated fibres. There were no onion bulb formations. These cases clinically resemble Refsum's disease, but differ in having no detectable biochemical abnormality, and a peripheral neuropathy which is not hypertrophic in type. They may represent unusual cases of spinocerebellar degeneration.

Retinitis pigmentosa occurs infrequently as an isolated finding in otherwise healthy individuals and families. Its association with deafness, with or without other neurological abnormalities is much less common but nevertheless well recognised. ${ }^{1}$ In heredopathia atactica polyneuritiformis (Refsum's disease), abetalipoproteinaemia, and the KearnsSayre syndrome, retinitis pigmentosa is associated with ataxia, peripheral neuropathy and deafness, and a specific biochemical or histochemical abnormality. In the present paper we describe the clinical and electrophysiological features of four patients with these signs but no detectable biochemical abnormality.

\section{Case histories}

The main clinical features of the patients are summarised in table 1 .

Case 1 (RPAH 4530 26)

A Maltese farm worker, aged 24 years, presented with unsteadiness of gait, loss of balance and poor vision which was first noticed when he was aged 6 years. His visual symptoms had become worse recently in that he was having difficulty reading and seeing in the dark. He had no other symptoms. His parents, who were unrelated, had no history of neurological disease, nor did his sister or two brothers. On examination, he was alert but IQ was 54

Address for reprint requests: Dr JG McLeod, Department of Medicine, University of Sydney, Sydney, NSW 2006, Australia.

Received 21 July 1982 and in revised form 14 October 1982 Accepted 20 October 1982
(WAIS). He had a speech impediment but was not dysarthric. He was of short stature, had a small head and pes cavus but no kyphoscoliosis. His visual acuity in the right eye was $6 / 60$ while in the left he could count fingers only. The right visual field was constricted but the left could not be tested. The optic discs were pale, the retinal vessels small in diameter and throughout the retinae there was scattered "bone corpuscle" pigmentation. The pupils were small and reacted poorly to light and accommodation. There was no ptosis and extraocular movements were full. The remaining cranial nerves were normal. There was no wasting in the limbs and tone and power were normal. There was no intention tremor in the upper limbs but rapid alternating movements were clumsy. Heel-knee-shin testing and heel-toe walking were unsteady and his gait was wide-based and ataxic. The upper limb reflexes were normal; the knee jerks could be elicited only with reinforcement and the ankle jerks were absent. Both plantar responses were extensor. There was no sensory loss. General examination was normal. On audiometry, there was high frequency sensorineural loss bilaterally, more severe on the right.

The patient was reviewed 4 years later when aged 28 His visual acuity was unchanged in the right eye but he could only just perceive light and bilateral cataracts were present. Extraocular movements were full and there was no ptosis. His hearing had deteriorated. There was now wasting of the small muscles of the feet; appreciation of light touch and pin prick was diminished on the feet; joint position sense was abnormal in the fingers and toes and two-point discrimination was impaired on the fingers and feet. Other physical signs were unchanged.

Case 2 (RPHA 3546 15)

A man aged 22 years was referred for investigation of progressive deterioration of his balance for 7 years, paraesthesiae in his feet for 4 years and numbness in the tips of 
Table 1 Summary of clinical features

\begin{tabular}{|c|c|c|c|c|c|c|c|c|c|c|}
\hline \multirow[t]{2}{*}{ Patient } & \multicolumn{3}{|c|}{ Age (yr) } & \multirow[t]{2}{*}{ Ocular signs } & \multirow{2}{*}{$\begin{array}{l}\text { Motor } \\
\text { examination }\end{array}$} & \multirow[t]{2}{*}{ Sensation } & \multirow[t]{2}{*}{ Reflexes } & \multirow[t]{2}{*}{ Other findings } & \multirow{2}{*}{$\begin{array}{l}\text { CSF } \\
\text { protein g/l }\end{array}$} & \multirow{2}{*}{$\begin{array}{l}\text { Neuro- } \\
\text { radiological } \\
\text { findings }\end{array}$} \\
\hline & Onset & Biopsy & $\begin{array}{l}\text { Final } \\
\text { review }\end{array}$ & & & & & & & \\
\hline 1 & 6 & 24 & 28 & $\begin{array}{l}\text { Retinitis pig- } \\
\text { mentosa } \\
\text { Optic atrophy } \\
\text { Cataracts } \\
\text { VAR: } 6 / 60 \\
\text { VAL: CF } \\
\text { Constricted } \\
\text { visual fields } \\
\text { Poorly reacting } \\
\text { pupils }\end{array}$ & $\begin{array}{l}\text { Wasted foot } \\
\text { muscles } \\
\text { Ataxia }\end{array}$ & $\begin{array}{l}\text { Impairment of } \\
\text { pinprick, light } \\
\text { touch, joint } \\
\text { position and 2- } \\
\text { point discrim- } \\
\text { ination }\end{array}$ & $\begin{array}{l}\text { Diminished } \\
\text { KJs } \\
\text { Absent AJs } \\
\text { Extensor } \\
\text { plantar } \\
\text { responses }\end{array}$ & $\begin{array}{l}\text { Low intelligence } \\
\text { Small head } \\
\text { Short stature } \\
\text { Partial deafness }\end{array}$ & 0.99 & $\begin{array}{l}\text { CT scan: enlarged } \\
\text { vallecula and IVth } \\
\text { ventricle, } \\
\text { suggestive of } \\
\text { cerebellar } \\
\text { atrophy }\end{array}$ \\
\hline 2 & 6 & 22 & - & $\begin{array}{l}\text { Retinitis pig- } \\
\text { mentosa } \\
\text { VAR: } 6 / 36 \\
\text { VAR: } 6 / 36 \\
\text { Constricted } \\
\text { visual fields } \\
\text { Nystagmus }\end{array}$ & $\begin{array}{l}\text { Intention } \\
\text { tremor } \\
\text { Ataxia }\end{array}$ & $\begin{array}{l}\text { All modalities } \\
\text { impaired }\end{array}$ & $\begin{array}{l}\text { All reflexes } \\
\text { absent. } \\
\text { Flexor plantar } \\
\text { responses }\end{array}$ & $\begin{array}{l}\text { Short distal } \\
\text { phalanges }\end{array}$ & $0 \cdot 27$ & \\
\hline 3 & 41 & 48 & 50 & $\begin{array}{l}\text { Retinitis pig- } \\
\text { mentosa } \\
\text { VAR: } 6 / 24 \\
\text { VAL: } 6 / 18 \\
\text { Constricted } \\
\text { visual fields } \\
\text { Nystagmus }\end{array}$ & $\begin{array}{l}\text { Intention } \\
\text { tremor } \\
\text { Ataxia } \\
\text { Slight } \\
\text { wasting of } \\
\text { intrinsic } \\
\text { hand muscles }\end{array}$ & $\begin{array}{l}\text { Impaired pin- } \\
\text { prick, vibra- } \\
\text { tion \& 2-point } \\
\text { discrimination }\end{array}$ & $\begin{array}{l}\text { Absent BJs } \\
\text { SJs, AJs } \\
\text { Flexor } \\
\text { plantar } \\
\text { responses }\end{array}$ & $\begin{array}{l}\text { Dry skin on } \\
\text { lower limbs } \\
\text { Partial } \\
\text { deafness }\end{array}$ & $0 \cdot 29$ & $\begin{array}{l}\text { CT scan: large } \\
\text { IVth ventricle } \\
\text { and cerebellar } \\
\text { atrophy }\end{array}$ \\
\hline 4 & 48 & 60 & 70 & $\begin{array}{l}\text { Retinitis pig- } \\
\text { mentosa } \\
\text { Cataracts } \\
\text { VAR: CF } \\
\text { VAL: CF } \\
\text { (totally blind } \\
\text { on review) }\end{array}$ & $\begin{array}{l}\text { Intention } \\
\text { tremor } \\
\text { Attaxia } \\
\text { Slight wast- } \\
\text { ing of intrinsic } \\
\text { hand muscles }\end{array}$ & $\begin{array}{l}\text { Impaired pin- } \\
\text { prick and } \\
\text { vibration }\end{array}$ & $\begin{array}{l}\text { Normal } \\
\text { flexor } \\
\text { plantar } \\
\text { responses }\end{array}$ & $\begin{array}{l}\text { Mild sensori- } \\
\text { neural deafness }\end{array}$ & 0.40 & $\begin{array}{l}\text { PEG: cerebellar } \\
\text { atrophy }\end{array}$ \\
\hline
\end{tabular}

VA: visual acuity; $\mathrm{CF}=$ able to count fingers only; $\mathrm{BJ}=$ biceps jerk; $\mathrm{SJ}=$ supinator; $\mathrm{KJ}=$ knee jerk; $\mathrm{AJ}=$ ankle jerk; $\mathrm{PEG}=$ pneumoencephalogram.

his fingers for 2 years. From the age of 6 years he had noticed a reduction in his peripheral vision and difficulty seeing at night. He had noticed no loss of hearing but had experienced some tinnitus 2 years ago. He was born in Sicily of unrelated parents and had two brothers and two sisters who were all apparently in good health. He did not work. On examination, he had short distal phalanges with thickened skin but he was of otherwise normal build with no scoliosis nor pes cavus. He did not have a rash or ichthyosis. His sense of smell was intact. Corrected visual acuity was $6 / 36$ in each eye and the visual fields were constricted. Retinitis pigmentosa was present in the periphery of both fundi. The optic discs were normal. Extraocular movements were full and bilateral horizontal nystagmus was present. There was no ptosis, and the pupils reacted normally to light and accommodation. There was no deafness. The cranial nerves were otherwise normal. There was no wasting and power and tone were normal in the upper and lower limbs. In the upper limbs there was a mild intention tremor and impairment of rapid alternating movements. His performance of the heel-knee-shin test was impaired, his gait was ataxic and Romberg's sign was positive. Deep tendon reflexes were absent and plantar responses flexor. Appreciation of light touch and pin-prick were impaired below the elbows and knees; vibration sense was absent below the elbows and iliac crests; joint position sense was impaired in the fingers and toes. Two point discrimination was greater than $5 \mathrm{~mm}$ in the fingers and $6 \mathrm{~cm}$ in the feet. The peripheral nerves were not enlarged and the general examination was normal. Pure tone audiogram was normal.

Case 3 (RPAH 5603 37)

For 7 years this policeman aged 48 years noticed progressive unsteadiness of gait, deteriorating vision and deafness. He had no difficulty reading but his night vision was poor and he could not see objects outside of his direction of gaze. He did not drink alcohol and ceased smoking in 1976. His parents were unrelated and there was no family history of visual failure nor of progressive neurological illness. On examination he was obese. There was no kyphoscoliosis, pes cavus nor peripheral nerve enlargement. His sense of smell was normal. Corrected visual acuity was $6 / 24$ in the right eye and $6 / 18$ in the left. The visual fields were markedly constricted and there was bilateral retinitis pigmentosa with normal optic discs. The pupils reacted normally to light and accommodation. There was no ptosis. Extraocular movements were full but there was bilateral horizontal nystagmus. He could not hear the whispered word and often missed normal conversation. Air conduction was better than bone conduction. The remainder of the cranial nerves was intact. There was slight wasting of 
Table 2 Results of nerve conduction studies

\begin{tabular}{|c|c|c|c|c|c|c|c|c|c|c|}
\hline \multirow[t]{3}{*}{ Patient } & \multicolumn{4}{|c|}{ Motor conduction velocity $(\mathrm{m} / \mathrm{s})$} & \multicolumn{6}{|c|}{ Sensory action potentials } \\
\hline & \multirow{2}{*}{$\begin{array}{l}\text { Age } \\
\text { Sex }\end{array}$} & \multirow{2}{*}{$\begin{array}{l}\text { Median } \\
\text { nerve }\end{array}$} & \multirow{2}{*}{$\begin{array}{l}\text { Ulnar } \\
\text { nerve }\end{array}$} & \multirow{2}{*}{$\begin{array}{l}\text { Lateral } \\
\text { popliteal }\end{array}$} & \multicolumn{2}{|c|}{ Median nerve } & \multicolumn{2}{|c|}{ Ulnar nerve } & \multicolumn{2}{|c|}{ Sural nerve } \\
\hline & & & & & $\begin{array}{l}\text { Latency } \\
\text { (ms) }\end{array}$ & $\begin{array}{l}\text { Amplitude } \\
(\mu \nu)\end{array}$ & $\begin{array}{l}\text { Latency } \\
\text { (ms) }\end{array}$ & $\begin{array}{l}\text { Amplitude } \\
(\mu v)\end{array}$ & $\begin{array}{l}\text { Latency } \\
\text { (ms) }\end{array}$ & $\begin{array}{l}\text { Amplitude } \\
(\mu v)\end{array}$ \\
\hline \multirow{5}{*}{$\begin{array}{l}1 \\
2 \\
3 \\
4 \\
\text { Control } \\
\text { range }^{2}\end{array}$} & M24 & 50 & 50 & 37 & $3 \cdot 2$ & 6 & $2 \cdot 3$ & 5 & NR & NR \\
\hline & M22 & 66 & 57 & 43 & - & 0 & - & 0 & - & 0 \\
\hline & M48 & 50 & 56 & 45 & $3 \cdot 0$ & 14 & - & 0 & NR & NR \\
\hline & M60 & 56 & 43 & 36 & $3 \cdot 3$ & 10 & $3 \cdot 2$ & 5 & $4 \cdot 2$ & 3 \\
\hline & $18-73$ & $50-66$ & $47-69$ & $41-56$ & $2 \cdot 4-3 \cdot 2$ & $11-40$ & $2 \cdot 1-3 \cdot 1$ & $7-36$ & & \\
\hline
\end{tabular}

(NR = No recording attempted).

interossei in the hands but there was no weakness. Tone was decreased in upper and lower limbs. Rapid alternating hand movements were normal but there was an intention tremor and heel-knee-shin test was impaired. The triceps and knee jerks were present but biceps, supinator and ankle jerks were absent. Plantar responses were flexor. The sensory examination in the upper limbs was normal. Appreciation of light touch and joint position were normal in the lower limbs but pain-sensation was absent below the knees and vibration sense was absent in the toes. Two point discrimination was greater than $10 \mathrm{~cm}$ on the feet. His gait was ataxic and wide based and Romberg's sign was positive. General examination was normal apart from small testes and dry skin on the legs. An audiogram revealed bilateral severe sensorineural hearing loss.

When reviewed two years later, he complained that his peripheral vision, balance and hearing had deteriorated slightly but he was still at work in a police station. His visual acuity and neurological status had not altered except that the knee jerks could be elicited only on reinforcement. Nerve conduction studies showed only a slight deterioration since the first study.

\section{Case 4 (RGHC HX 1340)}

A retired storeman aged 60 years first noticed unsteadiness of gait at the age of $\mathbf{4 8}$ years which slowly progressed forcing him to walk with a stick. His vision had slowly deteriorated over many years and retinitis pigmentosa had been diagnosed when he was aged 30 years. He had previously been a heavier drinker but in recent years drank 40-60 g of alcohol per day and smoked 20 cigarettes per day. There was no family history of visual loss or progressive neurological disease and his parents were unrelated. On examination, his verbal IQ was 122 (WAIS). The sense of smell was normal. He was able only to count fingers with both eyes. Cataracts and retinitis pigmentosa were present. There was no ptosis nor abnormality of extraocular movements, and the remaining cranial nerves were normal. There was no wasting, and power and tone were normal in upper and lower limbs. Finger-nose testing was accurate but rapid alternating movements of hands were abnormal and there was marked impairment of co-ordination of the lower limbs. The deep tendon reflexes were present and plantar responses were flexor. He had a wide based, ataxic gait. Sensation was normal in upper limbs but appreeiation of pin-prick was absent below the mid-calf level and vibration sense was absent at the ankles. Light touch and joint position were normal. General examination was normal apart from a patchy, generalised eczematous rash. Audiometry revealed bilateral high tone sensorineural hearing loss.

He was reviewed 10 years later. He was confined to a wheelchair because of severe ataxia. Speech was very slurred. He was completely blind; there were dense cataracts which obscured any view of the fundi. His pupils were $4 \mathrm{~mm}$ in diameter and unreactive to light and accommodation. He was not deaf. Apart from slight wasting of the 1st dorsal interossei, there was no wasting or weakness. Tone was normal but there was an intermittent coarse resting tremor in the fingers. Tests of co-ordination in the upper and lower limbs were grossly impaired. The deep tendon reflexes and plantar responses were unchanged. Vibration sense was absent at the iliac crests.

\section{HAEMATOLOGICAL AND BIOCHEMICAL} INVESTIGATIONS

Haemogloblin, white cell count, erythrocyte sedimentation rate, serum electrolytes, serum creatinine, serum proteins and electrophoretic pattern, liver function tests, serum cholesterol, fasting blood glucose, serum B12 and folate levels, thyroid function studies, serological tests for syphilis and urinalysis were normal. In two patients (cases 1 and 3) there was an increase in serum triglycerides and lipid electrophoretograms showed an elevation in the pre- $\beta$ lipoprotein concentration. The results of the cerebrospinal fluid (CSF) protein measurements are shown in table 1 . In all cases, the CSF cell count, and serological tests for syphilis, and glucose levels were normal.

Serum phytanic acid levels were measured in all patients, and were not increased.

\section{RADIOLOGICAL STUDIES}

Chest and skull radiographs were normal. Results of neuroradiological studies are summarised in table 1.

\section{ELECTROPHYSIOLOGICAL STUDIES (Table 2)}

Sensory action potentials were abnormal in all patients. Motor conduction velocity was normal in patients 2 and 3 but in patients 1 and 4, was reduced in the lateral popliteal nerve. The ulnar mixed nerve action potential was reduced in amplitude in patients 2 and 3 . A lateral popliteal mixed nerve action potential could not be recorded in any of the patients. 
Mixed nerve action potentials

\begin{tabular}{|c|c|c|c|}
\hline \multicolumn{2}{|c|}{ Ulnar nerve } & \multicolumn{2}{|c|}{ Lateral popliteal nerve } \\
\hline $\begin{array}{l}\text { Latency } \\
\text { (ms) }\end{array}$ & $\begin{array}{l}\text { Amplitude } \\
(\mu \nu)\end{array}$ & $\begin{array}{l}\text { Latency } \\
(\mathrm{ms})\end{array}$ & $\begin{array}{l}\text { Amplitude } \\
(\mu \nu)\end{array}$ \\
\hline $\begin{array}{l}\text { NR } \\
5.4 \\
5.9 \\
\text { NR }\end{array}$ & $\begin{array}{c}\text { NR } \\
4 \\
26 \\
\text { NR }\end{array}$ & $\bar{z}$ & $\begin{array}{l}0 \\
0 \\
0 \\
0\end{array}$ \\
\hline $4 \cdot 1-6 \cdot 7$ & $28-88$ & $5 \cdot 1-8 \cdot 1$ & $3-15$ \\
\hline
\end{tabular}

Table 3 Total myelinated fibre densities in sural nerves of patients and controls

\begin{tabular}{ll}
\hline Patient & Fibre density $\left(\times 10^{3} \mathrm{~mm}^{-2}\right)$ \\
\hline 1 & 1.66 \\
2 & $0 \cdot 78$ \\
3 & $5 \cdot 90$ \\
4 & 3.03 \\
\hline
\end{tabular}

Control range ${ }^{31} 3 \cdot 81-6 \cdot 42$ (mean 4.57, SD: $0 \cdot 89$ ).

\section{HISTOLOGICAL STUDIES}

The total myelinated fibre densities ${ }^{2}$ of the four sural nerves and the range in control patients are shown in table 3 . In cases 1,2 and 4 the densities were below the control range.
It may be seen from figs 1 and 2 that the density of myelinated fibres of all diameters was reduced in cases 1 and 2 but that larger diameter fibres were predominantly affected. By contrast, in case 4 , there is a marked reduction in the numbers of small myelinated fibres. Electron microscopy $^{2}$ revealed no specific abnormalities in any of the nerves. There was no evidence of demyelination, and onion bulbs were not seen.

\section{Discussion}

All four patients had retinitis pigmentosa with impaired visual acuity, night-blindness and consticted visual fields, a predominantly sensory peripheral neuropathy and cerebellar ataxia. Three of the patients had sensorineural deafness and three had radiological evidence of cerebellar atrophy. In other respects their clinical features differed. In patients 1 and 2 the onset of symptoms was before the age of 20 while in patients 3 and 4 , the age of onset of symptoms was after 40 , although retinitis pigmentosa has been observed in patient 4 when he was aged 30. Patient 1 was of low intelligence and had extensor plantar responses while the other three were of normal intelligence and had flexor plantar responses. Deep tendon reflexes were diminished or absent in patients 1,2 and 3 but were present in patient 4 . None of the patients gave a family history

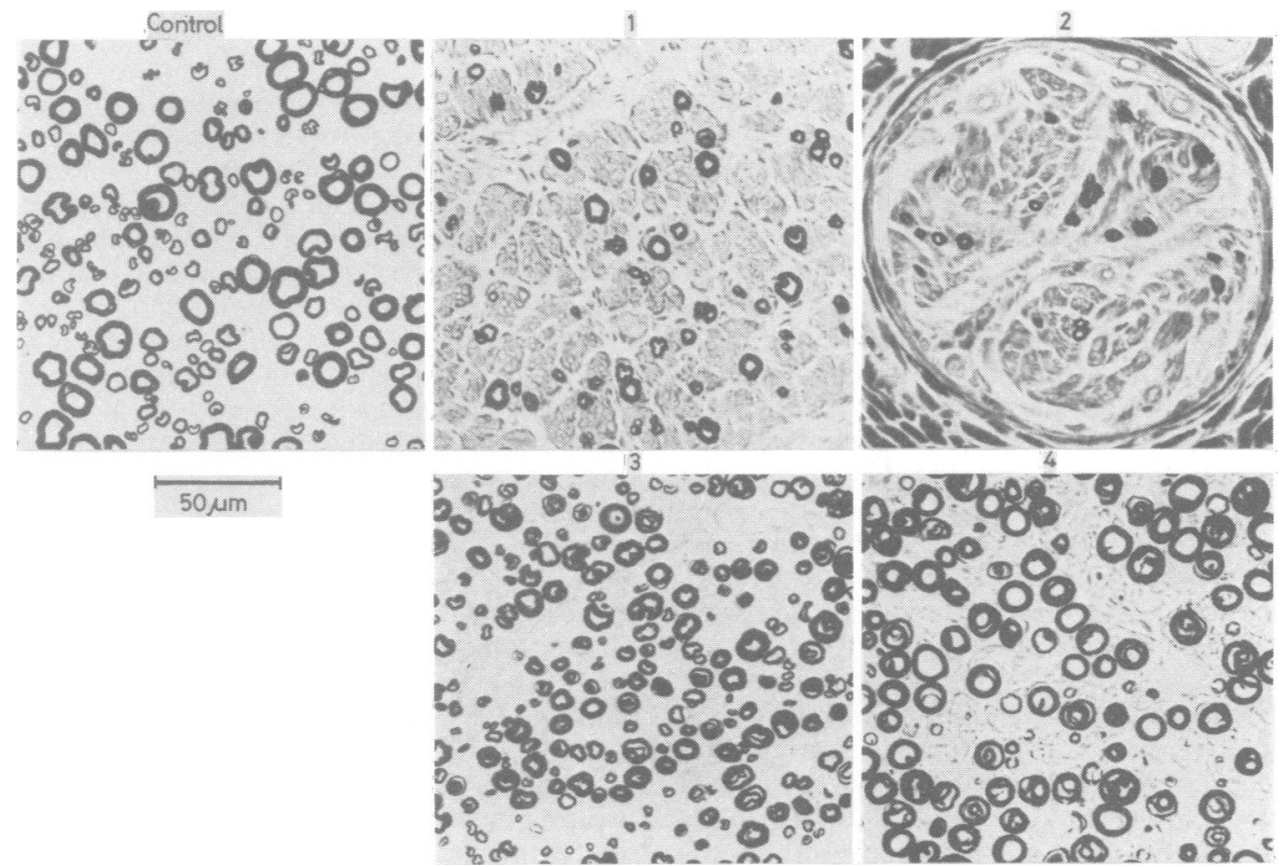

Fig 1 Photomicrographs of sections of sural nerves from a control subject and from cases 1-4.

Flemmings-Kulchitsky haematoxylin. 

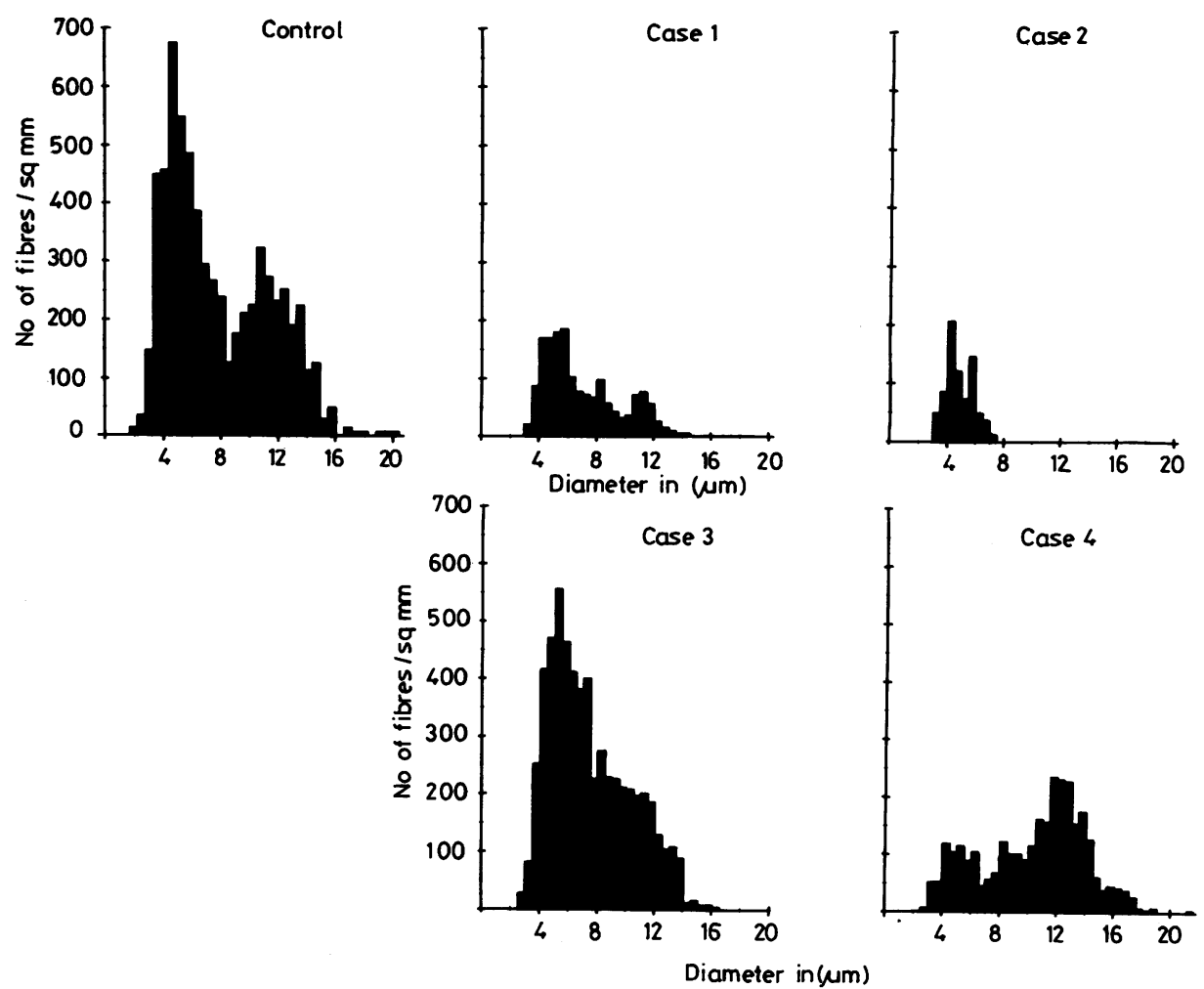

Fig 2 Diameter distribution of myelinated fibres in sural nerves of a control subject and of cases 1-4.

of parental consanguinity, progressive visual failure or progressive neurological disease. Therefore, if any of these patients has an inherited condition it is likely that the transmission is by an autosomal recessibe or X-linked recessive gene.

Abnormalities of nerve conduction, predominantly in sensory fibres, were found in all patients. On sural nerve biopsy there was a reduction in density of myelinated fibres in all patients, except case 3. No evidence of segmental demyelination was found on teased fibre studies or on electron microscopy, and no onion-bulb formations were visible.

In all cases, the diagnosis of Refsum's disease was suspected initially on clinical grounds, but finally excluded by the failure to demonstrate elevated serum phytanic acid levels that are essential for the diagnosis. ${ }^{3}$ The most constant clinical features of Refsum's disease, which has an autosomal recessive mode of inheritance, are retinitis pigmentosa, cerebellar ataxia, peripheral neuropathy and elevated CSF protein concentration without pleocytosis. ${ }^{3}$ The first three of these features were present in all our patients, but the CSF protein concentration was increased in only one case. Other clinical features which may be present in Refsum's disease are sen- sorineural deafness (present in three of our patients), abnormal pupillary reactions and cataracts (present in two of our patients), anosmia, cardiomyopathy, skeletal malformations and skin changes including icthyosis. ${ }^{3}$ The symptoms usually appear in the first three decades of life; in two of our patients the onset was in the fifth decade.

The peripheral neuropathy in Refsum's disease may have a relapsing and remitting course. Distal muscle wasting may be a prominent feature and the nerves may be palpably enlarged. Electrophysiological studies usually demonstrate marked slowing of motor conduction. ${ }^{3}$ The pathological features are those of a hypertrophic neuropathy, with segmental demyelination and reduplicated Schwann cell processes producing the characteristic appearance of onion-bulb formation. ${ }^{4}$ None of these clinical, electrophysiological and pathological features of a chronic demyelinating neuropathy were present in our cases.

Retinitis pigmentosa, deafness, ataxia, peripheral neuropathy and elevated CSF protein concentrations may be found in patients with the KearnsSayre syndrome which usually presents before the age of 20 years. ${ }^{5}$ None of the patients in the present 
study had either ptosis or ophthalmoplegia and only one had a raised CSF protein concentration. None of our patients had ECG evidence of heart block which is a frequent finding in the Kearns-Sayre syndrome. ${ }^{5}$ In patients with the Kearns-Sayre syndrome muscle biopsy shows ragged-red fibres on the trichrome stain and abnormal mitochondria on electron microscopy. ${ }^{6}$ None of our patients had a muscle biopsy performed but on clinical grounds, this diagnosis may be excluded.

Massion-Verniory, Dumont and Potvin ${ }^{7}$ described a 43-year-old man who developed retinitis pigmentosa, ataxia, amyotrophy and mild distal sensory loss at the age of 34 . His CSF protein was elevated. A nerve biopsy showed neither hypertrophic changes nor signs of active degeneration. One of this man's sisters had retinitis pigmentosa while another had atypical retinal pigmentary changes. However, neither his parents nor his four siblings had any neurological disease so the retinal changes might have been unrelated as could be the case in some or all of our patients. Dyck ${ }^{8}$ has classified this patient and a number of similar sibships (in whom serum phytanic acid was normal) as hereditary sensory and motor neuropathy type VII. However, the considerable degree of ataxia with minimal sensory loss in the patient reported by Massion-Verniory et al ${ }^{7}$ suggests that there might have been involvement of the cerebellum or spinocerebellar pathways or both as well as the peripheral nerves.

Two similarly affected individuals have been described in a family of four generations. ${ }^{9}$ Six other members of the family had distal muscle wasting and of these, one had optic atrophy and four had maturity onset diabetes mellitus. The amyotrophy and retinitis pigmentosa are apparently both dominantly inherited in this family but the former may be present in some individuals who have normal retinae. Refsum's disease and abetalipoproteinaemia were excluded in the propositus who also had congenital syphilis. The CSF protein was normal and motor conduction velocities were mildly reduced. Post mortem examination of one of the members of this family who developed neurological disease after the initial report in 1968 revealed severe demyelination of the peripheral nerves, spinal roots, dorsal columns, spinocerebellar tracts and optic chiasm. ${ }^{10}$ Although the clinical features of some of the members of this family resemble those of our four patients and the case of Massion-Verniory et $\mathrm{al}^{7}$ they probably in fact have a different disorder because demyelination was not found in the peripheral nerve biopsies of these patients.

Patients have been described as having Refsum's disease in whom the serum phytanic acid concentra- tions have been found to be normal. One patient ${ }^{1112}$ was subsequently shown to have the typical clinical and histopathological features of the Kearns-Sayre syndrome..$^{5}$ Although muscle pathology is lacking in the case of Solcher ${ }^{13}$ it is likely that his patient also had the Kearns-Sayre syndrome as there was bilateral ptosis and impairment of extraocular movements which are not features of Refsum's disease. Another patient with the clinical features of Refsum's syndrome with normal phytanic acid levels ${ }^{14}$ had a liver biopsy in which there were a number of abnormalities including abnormal vesiculated mitochondria. However, the appearance was not that of the abnormal liver cell mitochondria in the Kearns-Sayre syndrome in which are seen fused arrays of cristae. ${ }^{12}$ This patient subsequently died and was presented as a case of diffuse cerebral sclerosis $^{15}$ with patchy demyelinated sudanophilic lesions and punctate perivascular calcification in the brain. Phytanic acid metabolism in cultured skin fibroplasts was normal. Ron and Pearce ${ }^{16}$ described a 27-year-old male patient whose symptoms began at the age of 8 years and who had signs and symptoms which were consistent with Refsum's syndrome except for extensor plantar responses and normal CSF protein. Motor conduction velocities were only mildly slowed. No phytanic acid was detected in the serum and there was no response to a phytate-free diet.

Retinitis pigmentosa, sensorineural deafness, cerebellar ataxia and peripheral neuropathy occur together in Cockayne's syndrome. ${ }^{17}$ However this condition should be readily recognisable because of certain clinical features which include onset of infancy, microcephaly, dwarfism, kyphosis, flexion deformities, loss of subcutaneous fat, a distinctive physiognomy, anhidrosis, marked cutaneous photosensitivity to ultraviolet light and deterioration in intellect. Death often occurs in childhood. ${ }^{18}$ The major abnormality in the brains of patients with Cockayne's syndrome are patchy demyelination and perivascular calcification. ${ }^{18}$ Marked slowing of motor conduction velocity was recorded in one patient with Cockayne's syndrome whose nerve biopsy showed segmental demyelination. ${ }^{19}$ Apart from the presence of retinitis pigmentosa, deafness, ataxia and neuropathy, none of our cases have other features to suggest Cockayne's syndrome except case 1 who is mentally retarded and of short stature. He does not have skin photosensitivity nor a demyelinating neuropathy. Unlike most cases, he was still able to perform menial tasks at the age of 28. However a patient has been described recently who probably has Cockayne's syndrome but was atypical in that her intellectual and motor functions were moderately well preserved when seen at the 
age of 25 years. ${ }^{20}$

The neurological signs in abetalipoproteinaemia include retinitis pigmentosa, ataxia, peripheral neuropathy, but not usually deafness. These signs are manifest by the age of 20 years and are preceded by a history of diarrhoea and steatorrhoea of some years duration. Usually, patients with abetalipoproteinaemia have marked muscle wasting and weakness, kyphoscoliosis and are confined to a wheelchair by the age of $20 . .^{21}$ The non-neurological hallmarks of the condition are the presence of acanthocytes in the blood film, the absence of betalipoproteins and low concentrations of cholesterol in the serum. None of our patients had any of these abnormalities.

Retinitis pigmentosa, deafness, ataxia and mental retardation may occur together in patients with Hallgren's syndrome ${ }^{22}$ or with juvenile or adult onset types of lipidosis. ${ }^{23}$ However, there is no clinical evidence of peripheral neuropathy in patients with these disorders. In Hallgren's syndrome, deafness is congenital and usually profound, while patients with a lipidosis frequently have epilepsy, myoclonus or both which was not the case in any of our patients.

Retinitis pigmentosa is very rare in Friedreich's ataxia, but may occur in association with olivoponto-cerebellar atrophy, and some other hereditary ataxias. ${ }^{24-27}$ None of our patients had the clinical features of Friedreich's ataxia or the characteristic reduction in density of large diameter fibres in the sural nerve. ${ }^{28}$ However it is possible that they represent sporadic cases of olivo-ponto-cerebellar atrophy, or a spinocerebellar degeneration. Patient 1 had evidence of pyramidal tract involvement which is consistent with olivo-ponto-cerebellar atrophy $^{29}$ or spinocerebellar degenerations. ${ }^{30}$ In three cases there was radiological evidence of cerebellar atrophy, and the electrophysiological and pathological features of the peripheral neuropathy were consistent with those reported in these conditions. $^{2}$ The precise relationship of the disorder affecting these patients to other degenerative diseases involving cerebellum, spinal cord and peripheral nerves, remains uncertain.

\section{References}

${ }^{1}$ Bell J. Retinitis pigmentosa and allied diseases. In: Treasury of Human Inheritance Vol 2 Part 1. Cambridge University Press, 1933:1-28.

${ }^{2}$ McLeod JG, Evans WA. Peripheral neuropathy in spinocerebellar degeneration. Muscle Nerve 1981;4: 51-61.

${ }^{3}$ Refsum S. Heredopathia atactica polyneuritiformis (Refsum's disease). In: Dyck PJ, Thomas PK, Lam- bert EH, eds. Peripheral Neuropathy. Philadelphia: Saunders, 1975:868-72.

${ }^{4}$ Fardeau M. Pathology of Refsum's disease. In: Dyck PJ, Thomas PK, Lambert EH, eds. Peripheral Neuropathy. Philadelphia: Saunders, 1975:881-90.

5 Berenberg RA, Pellock JM, Di Mauro S, et al. Lumping or splitting? "Ophthalmoplegia-plus" or KearnsSayre syndrome? Ann Neurol 1977;1:37-54.

${ }^{6}$ Karpati G, Carpenter S, Larbrisseau A, Lafontaine R. The Kearns-Shy syndrome. J Neurol Sci 1975;19: 133-51.

${ }^{7}$ Massion-Verniory L, Dumont E, Potvin AM. Rétinite pigmentaire familiale compliquée d'une amyotrophie neurale. Rev Neurol (Paris) 1946;78:561-71.

${ }^{8}$ Dyck PJ. Atrophy affecting peripheral motor, sensory and autonomic neurons. In: Dyck PJ, Thomas PK, Lambert EH, eds. Peripheral Neuropathy. Philadelphia: Saunders, 1975:864.

9 Furukawa T, Takagi A, Nakao K, Sugita H, Tsukagoshi H, Tsubaki T. Hereditary muscular atrophy with ataxia, retinitis pigmentosa, and diabetes mellitus. A clinical report of a family. Neurology (Minneap) 1968;18:942-7.

${ }^{10}$ Kondo K. Peripheral neuropathy associated with ataxia, retinitis pigmentosa and diabetes mellitus. In: Vinken PJ, Gruyn GW, eds. Handbook of Clinical Neurology Vol 42. Amsterdam: North Holland Publishing Company, 1981:334-5.

" Shy GM, Silberberg DM, Appel SM, Mishkin MM, Godfrey EH. A generalised disorder of nervous system, skeletal muscle and heart resembling Refsum's disease and Hurler's syndrome. I. Clinical, pathological and biochemical characteristics. Am J Med 1967;42:163 7.

${ }^{12}$ Gonatas NK, Evangelista I, Martin J. A generalised disorder of nervous system, skeletal and heart resembling Refsum's disease and Hurler's syndrome. II. Ultrastructure. Am J Med 1967;42:169-78.

${ }^{13}$ Solcher H. Über hirnveränderungen bei heredopathia atactica (Refsum). Acta Neuropathol (Berl) 1973; 24:92-5.

${ }^{14}$ Kolodny EM, Hass WK, Lane B, Drucker WD. Refsum's syndrome. Report of a case including electron microscopic studies of the liver. Arch Neurol 1965;12:583-96.

15 Hayden HJ, Reagan TJ, Mize CE, Herndon JH, Steinberg D. Diffuse cerebral sclerosis erroneously reported as Refsum's disease. Arch Neurol 1973;28:304-7.

${ }^{16}$ Ron MA, Pearce J. Refsum's syndrome with normal phytate metabolism. Acta Neurol Scand 1971; 47:646-9.

${ }^{17}$ Cockayne EA. Case reports: dwarfism with retinal atrophy and deafness. Arch Dis Child 1946;21:52-4.

${ }^{18}$ Guzzetta F. Cockayne-Neill-Dingwall syndrome. In: Vinken PJ, Bruyn GW, eds. Handbook of Clinical Neurology Vol 13. Amsterdam: North Holland Publishing Company, 1972:431-40.

19 Moosa A, Dubowitz V. Peripheral neuropathy in Cockayne's syndrome. Arch Dis Child 1970;45:674-7.

${ }^{20}$ Kennedy RM, Rowe VD, Kepes JJ. Cockayne syndrome; an atypical case. Neurology (Minneap) 
1980;30:1268-72.

${ }^{21}$ Schwartz JF. Acanthocytosis-abetalipoproteinaemia. In: Vinken PJ, Bruyn GW, eds. Handbook of Clinical Neurology Vol 13. Amsterdam: North Holland Publishing Company, 1972:413-30.

${ }^{22}$ Hallgren B. Retinitis pigmentosa combined with congenital deafness, with vestibulo-cerebellar ataxia and mental abnormality in a proportion of cases. A clinical and genetico-statistical study. Acta Psychiatr Scand Suppl 1959;138:1-101.

${ }^{23}$ Cummings JN. The lipidoses. In: Vinken PJ, Bruyn GW, eds. Handbook of Clinical Neurology Vol 10. Amsterdam: North Holland Publishing Company, 1970: 325-61.

${ }^{24}$ Weiner LP, Konigsmark BW, Stoll Jnr J, Magladery JW. Hereditary olivopontocerebellar atrophy with retinal degeneration. Arch Neurol 1967;16:364-76.

${ }^{25}$ Ryan SJ, Smith RE. Retinopathy associated with hereditary olivopontocerebellar degeneration. Am J Ophthalmol 1971;71:838-47.

${ }^{26}$ Botermans CHG. Primary pigmentary retinal degenera- tion and its association with neurological diseases. In: Vinken PJ, Bruyn GW, eds. Handbook of Clinical Neurology Vol 13. Amsterdam: North Holland Publishing Company, 1972:148-379.

${ }^{27}$ Harding AE. The clinical features and classification of the late onset autosomal-dominant cerebellar ataxias: a study of 11 families including descendants of the 'Drew family of Walworth'. Brain 1982;105:1-28.

${ }^{28}$ McLeod JG. An electrophysiological and pathological study of peripheral nerves in Friedreich's ataxia. $J$ Neurol Sci 1971;12:333-49.

${ }^{29}$ Berciano J. Olivopontocerebellar atrophy. A review of 117 cases. J Neurol Sci 1982;53:253-72.

${ }^{30}$ Harding AE. Friedreich's ataxia: a clinical and genetic study of 90 families with an analysis of early diagnostic criteria and intrafamilial clustering of clinical features. Brain 1981;104:589-620.

${ }^{31}$ Low PA, McLeod JG, Prineas JW. Hypertrophic Charcot-Marie-Tooth disease. Light and electron microscope studies of the sural nerve. J Neurol Sci 1978;35:93-115. 